\title{
Fluorescence Mode XANES Spectroscopy as a Powerful Tool for Redox-Isomerism Studies in Ultrathin Films
}

\author{
Alexander V. Shokurov, ${ }^{a}$ Daria S. Kutsybala, ${ }^{a}$ Alexander G. Martynov, ${ }^{a}$ \\ Alexey V. Yagodin, ${ }^{a}$ Yulia G. Gorbunova, ${ }^{a}{ }^{\mathrm{a} b}$ Dmitri Novikov, $^{\mathrm{c}}$ Artem V. Bakirov, ${ }^{\mathrm{d}}$ \\ Maxim A. Shcherbina, ${ }^{d}$ Sergei N. Chvalun, ${ }^{d}$ Vladimir V. Arslanov, ${ }^{a}$ \\ and Sofiya L. Selektor ${ }^{\mathrm{a}}$
}

Dedicated to Professor Dieter Wöhrle on the occasion of his 80th Anniversary

\begin{abstract}
${ }^{a}$ A.N. Frumkin Institute of Physical Chemistry and Electrochemistry of Russian Academy of Sciences, 119071Moscow, Russia ${ }^{\mathrm{b}}$ N.S. Kurnakov Institute of General and Inorganic Chemistry of Russian Academy of Sciences, 119071 Moscow, Russia 'Deutsches Elektronen-Synchrotron, PETRA III, D-22607 Hamburg, Germany

${ }^{\mathrm{d} N . S}$. Enikolopov Institute of Synthetic Polymeric Materials of Russian Academy of Sciences, 117393 Moscow, Russia

${ }^{\circledR}$ Corresponding authorE-mail: Shokurov@phyche.ac.ru
\end{abstract}

\begin{abstract}
Redox-isomerism, i.e. intramolecular electron transfer that results in isostructural compounds with different charge distribution between metal center and ligands, and thus in their different physico-chemical characteristics, attracts considerable interest from the standpoint of development of novel molecular devices. However, direct determination of the valence states of the coordinating cations remains an urgent task. In the present work on the example of cerium bis-tetra-15-crown-5-phthalocyaninate it was shown that synchrotron source X-ray absorption near edge structure spectroscopy in fluorescent mode is a powerful method that allows one to directly observe valence states of the metal cations in redox-isomeric materials even in ultrathin single-layer Langmuir-Blodgett films, which are notably hard to study due to extremely small amounts of matter and low dimensionality.
\end{abstract}

Keywords: XANES, X-ray absorption spectroscopy, redox-isomerism, phthalocyanine, cerium, Langmuir monolayer.

\section{Флуоресцентная XANES спектроскопия как мощный инструмент Аля изучения редокс-изомерии в ультратонких пленках}

\author{
А. В. Шокуров, ${ }^{a}$ А. С. Куцыбала, ${ }^{a}$ А. Г. Мартынов, ${ }^{a}$ А. В. Ягодин, ${ }^{a}$ \\ Ю. Г. Горбунова, ${ }^{\mathrm{a}, \mathrm{b}}$ A. Новиков, ${ }^{\mathrm{c}}$ А. В. Бакиров, ${ }^{\mathrm{d}}$ М. А. Щербина, ${ }^{\mathrm{d}}$ C. Н. Чвалун, ${ }^{\mathrm{d}}$ \\ B. В. Арсланов, ${ }^{a}$ C. А. Селектор ${ }^{a}$
}

${ }^{\mathrm{a}}$ Институт физической химии и электрохимии им. А.Н. Фрумкина РАН, 119071 Москва, Россия
${ }^{\mathrm{b}}$ Институт общей и неорганической химии им. Н.С. Курнакова РАН, 119071 Москва, Россия
${ }^{\text {' } Н а у ч н ы и ̆ ~ ц е н т р ~ D Е S Y ~(Н е м е и к и и ̆ ~ э л е к т р о н н ы и ̆ ~ с и н х р о т р о н), ~ D-22607 ~ Г а м б у р г, ~ Г е р м а н и я ~}$
${ }^{\mathrm{d}}$ Институт синтетических полимерных материалов им. Н.С. Ениколопова РАН, 117393 Москва, Россия

Редокс-изомерия, то есть внутримолекулярный перенос электрона, который приводит к образованию изоструктурных соединений с различным распределением заряда между металлочентром и лигандами, a, следовательно, и с различными физико-химическими свойствами, вызывает значительный интерес с точки зрения разработки новых молекулярных устройств. Однако прямое определение валентных состояний координирующих катионов остается актуальной задачей. В данной работе на примере бис-тетра-15краун-5-фталоцианината иерия показано, что спектроскопия рентгеновского поглощения вблизи краевой структуры во флуоресиентном режиме с использованием синхротронного излучения является мощчным методом, позволяющим непосредственно наблюдать валентные состояния ионов металла в редокс-изомерных материалах даже в ультратонких однослойных пленках Ленгмюра-Блоджетт, которые особенно трудно изучать из-за чрезвычайно мальх количеств вещеества и низкой размерности.

Ключевые слова: XANES, рентгеновская спектроскопия поглощения, редокс изомерия, фталоцианин, церий, монослой Ленгмюра. 


\section{Introduction}

Organic complexes of multivalent metals may exhibit a reversible intramolecular electron transfer between the coordinating cation and a redox-active ligand(s). The products of this transformation are isostructural and retain the same overall charge, and thus are considered isomers. This effect is called redox isomerism (or valence tautomerism) and it was first reported by Pierpont and Buchanan in 1980 for a substituted $o$-benzoquinone complex of cobalt. ${ }^{[1]}$ Since then, several instances of this phenomenon were demonstrated on the examples of complexes of $d$-metals and some $f$-elements. ${ }^{[2-9]}$ It should be noted that in most cases, these transformations are driven by extreme changes of temperature, hydrostatic pressure, and dramatic changes of environment or application of intensive lighting in bulk state. As was shown by us earlier, ${ }^{[9]}$ the molecular reorientation of the discotic phthalocyaninate sandwich complexes at the air-water interface can be another pathway for redox-isomerization. In that work, a reversible $\mathrm{Ce}^{4+} \leftrightarrow \mathrm{Ce}^{3+}$ transformation was achieved in a $2 \mathrm{D}$ system, upon compression/expansion of a Langmuir monolayer of a crown-substituted cerium bisphthalocyaninate $\mathbf{C e}\left[(\mathbf{1 5 C 5})_{4} \mathbf{P c}_{2}\right.$ (Figure 1).

However, like in most cases, direct confirmation of valence state of the metal centre in the process of redoxisomerization remains a hard task, and is usually deduced from secondary characteristics: change of the UV-Vis absorbance and/or EPR spectra, magnetic properties, etc. ${ }^{[10-12]}$ Moreover, these measurements become even harder when applied to planar supramolecular systems. In this work, we show that synchrotron source X-ray absorption near edge structure (XANES) spectroscopy in fluorescent mode is a powerful method that can allow one to directly observe valence states of the redox-isomeric materials no matter the dimensionality of the system under study. Previously studied ${ }^{[9,12]}$ ultrathin single-layer Langmuir-Blodgett films of $\mathbf{C e}\left[(\mathbf{1 5 C 5})_{4} \mathbf{P c}\right]_{2}$ exhibited redox-isomerization that has been proved mainly by means of absorbance spectra and X-ray photoelectron spectroscopy ${ }^{[9]}$ and were chosen as an established example of the redox-isomeric $2 \mathrm{D}$ system.

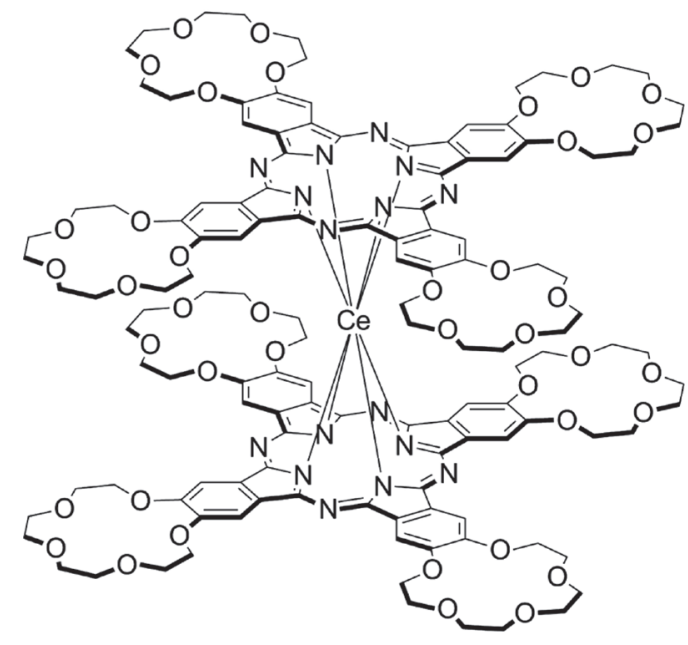

Figure 1. Chemical structure of the studied complex $\mathrm{Ce}\left[(15 \mathrm{C} 5)_{4} \mathrm{Pc}\right]_{2}$.

\section{Experimental}

The studied compound $\mathbf{C e}\left[(\mathbf{1 5 C 5})_{4} \mathbf{P c}\right]_{2}$ was synthesized according to the previously described procedure ${ }^{[13]}$ starting from tetra-15-crown-5-phthalocyanine. ${ }^{[14]}$

For Langmuir-Blodgett experiments and formation of drop cast films, the studied $\mathbf{C e}\left[(\mathbf{1 5 C 5})_{4} \mathbf{P c}\right]_{2}$ phthalocyaninate was solubilized at a concentration in the range of $(1-1.5) \cdot 10^{-5} \mathrm{M}_{\text {in }} \mathrm{CHCl}_{3}$ (HPLC grade, ethanol-stabilized, acquired from Sigma-Aldrich).

Langmuir-Blodgett device KSV Minitrough (Finland) with PTFE trough with surface area of $273.0 \mathrm{~cm}^{2}$ and moveable barriers made of hydrophilic polyacetal were used for Langmuir monolayer formation. The monolayers were formed by spreading the solutions onto the air/water interface using a chromatographic syringe. Then the system was left undisturbed for 10-15 min in order for the solvent to evaporate from the interface. After that, monolayer compression at the rate of $5 \mathrm{~mm} \cdot \mathrm{min}^{-1}$ commenced. Transfer of Langmuir monolayers onto solid substrates was carried by Langmuir-Blodgett technique (vertical transfer). All studied films were single-layered. Ultrapure water $(18 \mathrm{M} \Omega \mathrm{cm})$ deionized by Millipore Milli-Q water purification system was used as a subphase in Langmuir monolayer studies.

X-Ray absorption near edge structure (XANES) measurements were carried out at the in situ and nano X-ray diffraction beamline P23 at the PETRA III storage ring at the Deutsches Elektronen-Synchrotron DESY. The X-ray beam from a spectroscopic undulator was monochromatized by a cryogenically cooled double crystal $\mathrm{Si}(111) / \mathrm{Si}(111)$ monochromator. Two B4C covered flat mirrors were used for harmonics rejection. Due to the very low concentration of the target atoms in the samples, the XANES data were recorded in the fluorescence detection mode with an Amptek XR100SDD silicon drift detector. $\mathrm{Cu} K$ absorption line was used as the energy scale calibration reference.

All experiments were carried out under ambient conditions: air atmosphere, air and subphase temperature of $20 \pm 1^{\circ} \mathrm{C}$.

\section{Results and Discussion}

As was described in detail in our previous work, ${ }^{[9]}$ the cerium metal centre of $\mathbf{C e}\left[(\mathbf{1 5 C 5})_{4} \mathbf{P c}\right]_{2}$ in chloroform solution strictly exhibits $4^{+}$oxidation state. Upon spreading of this solution onto air/water interface and evaporation of the solvent, the metal centre assumes the oxidation state of $3^{+}$due to the intramolecular transfer of an electron from tetra-crown-phthalocyaninato-ligands. Lateral compression of the resulting Langmuir monolayer to high surface pressure values leads to the reverse process that results in the $\mathrm{Ce}^{4+}$ cation. Expansion of such a monolayer is again followed by transition of cerium cations into $3^{+}$state.

The first transformation arises due to the fact that discotic $\mathbf{C e}\left[(\mathbf{1 5 C 5})_{4} \mathbf{P c}\right]_{2}$ molecules assume face-on orientation at the interface upon the spreading, where one of the ligand decks comes into contact with the water subphase, while the other one is not. This makes crownphthalocyanine decks non-equivalent and becomes a driving force for the intramolecular electron transfer that leads to $\mathrm{Ce}^{4+} \rightarrow \mathrm{Ce}^{3+}$ transition. Compression of this monolayer leads to re-orientation of the phthalocyaninate molecules into edge-on position, where both macrocyclic ligands are located at the interface in the same way, thus relieving the effect of uncompensated surface forces, and thus brings on the reverse intramolecular electron transfer, which results in $\mathrm{Ce}^{3+} \rightarrow \mathrm{Ce}^{4+}$ transition. 
Despite the fact that both these phenomena can be monitored in situ by UV-Vis absorbance measurements, direct determination of the valence (oxidation state) of the metal centre is a difficult task. In the aforementioned work, it was elucidated for Langmuir-Blodgett films (LBF) obtained from monolayers containing $\mathbf{C e}\left[(\mathbf{1 5 C 5})_{4} \mathbf{P c}\right]_{2}$ in one or another redox-isomeric states by means of X-ray photoelectron spectroscopy (XPS). Because of low dimensionality of the studied systems, and corresponding low amount of matter in them (and metal ions especially), these measurements took large amount of time due to high expositions required to achieve meaningful signal/noise ratios. And even in such conditions the accuracy of these measurements remain very low. In addition, the interpretation of the results of XPS measurements is complicated by the absence of generally accepted reference XPS spectra of cerium ion in different valence states in the literature.

Here, direct confirmation of the redox-isomeric state of the studied complex in the LBFs via determination of the cerium valence was achieved by measurement of the XANES spectra along the cerium $L_{I I I} \mathrm{X}$-ray absorption edge. It is well known that the form of the X-ray absorption edge differs for cations with different oxidation states. Moreover, as literature data for various cerium compounds show, the difference of $L_{I I I}$ edge for tri- and tetravalent Ce is quite dramatic. ${ }^{[15-17]}$

As can be seen in Figure 2, XANES spectrum for a film obtained by drop-casting from $\mathbf{C e}\left[(\mathbf{1 5 C 5})_{4} \mathbf{P c}\right]_{2}$ solution (curve 1) exhibits a classical two-peak structure, pointing to a purely $4^{+}$oxidation state of the metal centre. This is quite expected since it is exactly the state, in which the Ce cation exists in solution, and in absence of surface forces of the air/water interface, there is no driving force for a change.

In contrast, XANES spectrum of a Langmuir-Blodgett film, transferred at low surface pressure (ca. $10 \mathrm{mN} / \mathrm{m})$, i.e., straight after the first redox-isomeric transformation that results in $\mathrm{Ce}^{3+}$ metal center (Figure 2, curve 2) shows a $L_{I I I}$ edge form characteristic to this oxidation state.

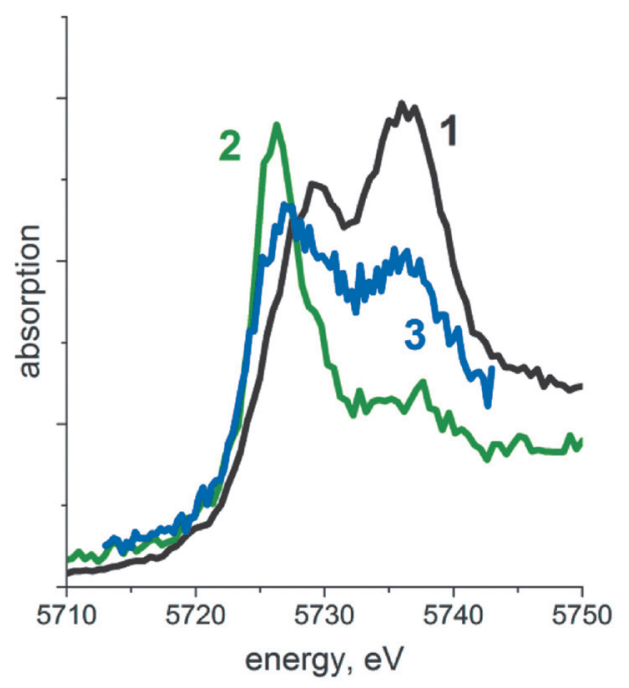

Figure 2. XANES spectra of $\mathbf{C e}\left[\left(\mathbf{1 5 C 5}_{4}\right)_{4} \mathbf{P c}\right]_{2}$ cast film (1), LBF transferred at low surface pressure (2), and LBF transferred at high surface pressure (3).
A film, transferred at higher surface pressures ( $c a$. $35 \mathrm{mN} / \mathrm{m}$ ), where a reverse transition to a redox-isomer with tetravalent cerium cation is observed by both UV-Vis absorbance and XPS spectrometry, ${ }^{[9]}$ demonstrates a more complex pattern (Figure 2, curve 3). It can be seen, that spectrum associated with neither pure $\mathrm{Ce}^{3+}$ nor $\mathrm{Ce}^{4+}$ is observed, but a superposition of them. This signifies that both redox-isomeric states are present in the LBF under question. This is not surprising, since the same conclusion was deduced from the XPS data in the previous work. It should be noted, however, that this result is more evident and unambiguous in the present work, since XANES spectra of the studied redox-isomers differ much greatly than the XPS spectra of the same systems. This is because in contrast to heavily overlapping electron binding energies of $\mathrm{Ce}^{3+}$ and $\mathrm{Ce}^{4+}$ measured by XPS, Ce $L_{I I I}$ absorption edge structures, observed by XANES, are easily distinguishable.

\section{Conclusions}

Thus, we show that synchrotron source X-ray absorption near edge structure spectroscopy in fluorescent mode is a powerful method that can allow one to directly observe valence states of the metal cations in redoxisomeric materials in ultrathin films, which are notably hard to study due to extremely small amounts of matter and low dimensionality.

Acknowledgements. The present work was financially supported by Russian Science Foundation project No.1973-20236. We acknowledge DESY (Hamburg, Germany), a member of the Helmholtz Association HGF, for the provision of experimental facilities. The Langmuir-Blodgett experiments were partially performed using equipment of CKP FMI IPCE RAS.

\section{References}

1. Buchanan R.M., Pierpont C.G. J. Am. Chem. Soc. 1980, 102, 4951-4957.

2. Hendrickson D.N., Pierpont C.G. In: Spin Crossover in Transition Metal Compounds II, Vol. 1. Springer-Verlag, 2004. p. 63-95.

3. Tezgerevska T., Alley K.G., Boskovic C. Coord. Chem. Rev. 2014, 268, 23-40.

4. Drath O., Boskovic C. Coord. Chem. Rev. 2018, 375, 256266.

5. Abakumov G.A., Razuvaev G.A., Nevodchikov V.I., Cherkasov V.K. J. Organomet. Chem. 1988, 341, 485-494.

6. Abakumov G.A., Cherkasov V.K., Nevodchikov V.I., Kuropatov V.A., Yee G.T., Pierpont C.G. Inorg. Chem. 2001, 40, 2434-2436.

7. Fedushkin I.L., Maslova O.V., Morozov A.G., Dechert S., Demeshko S., Meyer F. Angew. Chem. Int. Ed. Engl. 2012, 51, 10584-10587.

8. Fedushkin I.L., Maslova O.V., Baranov E.V., Shavyrin A.S. Inorg. Chem. 2009, 48, 2355-2357.

9. Selektor S.L., Shokurov A.V., Arslanov V.V., Gorbunova Y.G., Birin K.P., Raitman O.A., Morote F., Cohen-Bouhacina T., Grauby-Heywang C., Tsivadze A.Y. J. Phys. Chem. C 2014, $118,4250-4258$. 
10. Martynov A.G., Safonova E.A., Tsivadze A.Y., Gorbunova Y.G. Coord. Chem. Rev. 2019, 387, 325-347.

11. Evangelio E., Ruiz-Molina D. Eur. J. Inorg. Chem. 2005, 2005, 2957-2971.

12. Selector S.L., Shokurov A.V., Arslanov V.V., Gorbunova Y.G., Raitman O.A., Isakova A.A., Birin K.P., Tsivadze A.Y. Russ. J. Electrochem. 2012, 48, 218-233.

13. Birin K.P., Gorbunova Y.G., Tsivadze A.Y. J. Porphyrins Phthalocyanines 2006, 10, 931-936.
14. Martynov A.G., Berezhnoy G.S., Safonova E.A., Polovkova M.A., Gorbunova Y.G., Tsivadze A.Y. Macroheterocycles 2019, 12, 75-81.

15. Takahashi Y., Shimizu H., Usui A., Kagi H., Nomura M. Geochim. Cosmochim. Acta 2000, 64, 2929-2935.

16. Zhang J., Wu Z., Liu T., Hu T., Wu Z., Ju X. J. Synchrotron Radiat. 2001, 8, 531-532.

17. Modeshia D.R., Wright C.S., Payne J.L., Sankar G., Fiddy S.G., Walton R.I. J. Phys. Chem. C 2007, 111, 14035-14039.

Received 17.10.2019

Accepted 30.10.2019 